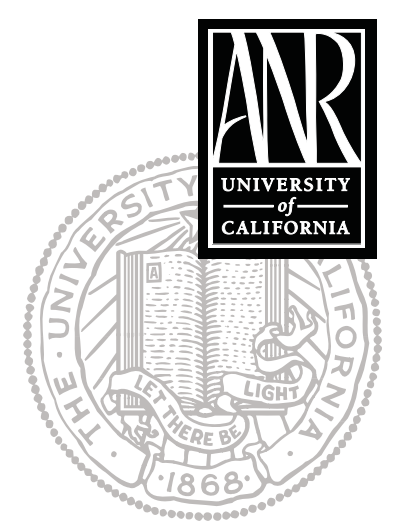

UNIVERSITY OF CALIFORNIA

Division of Agriculture and Natural Resources http://anrcatalog.ucdavis.edu
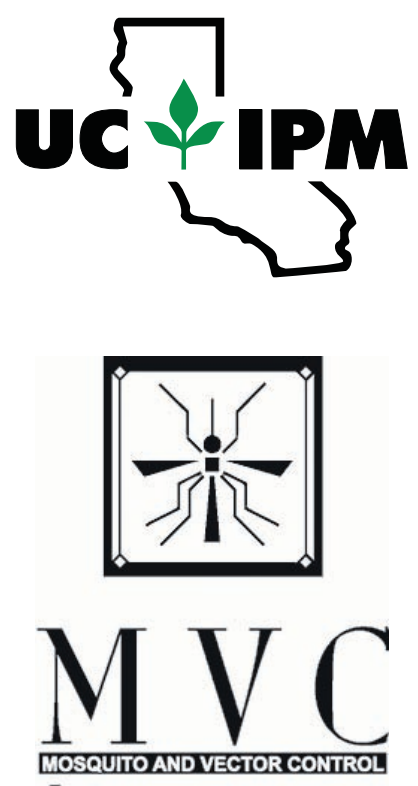

ASSOCIATION Of CALIFORNIA
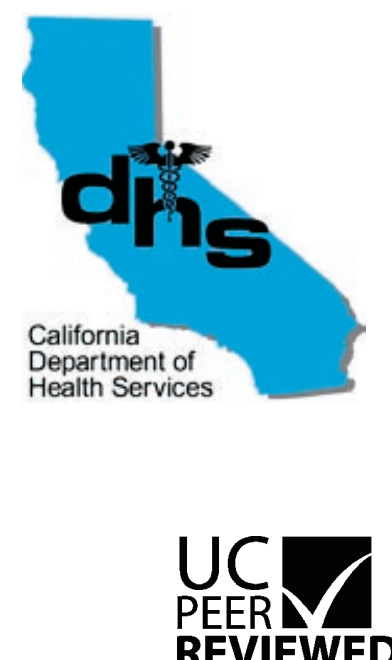

\title{
Managing Mosquitoes On the Farm
}

SHARON P. LAWLER and GREGORY C. LANZARO, Department of Entomology, University of California, Davis

\section{WHY YOU SHOULD CARE ABOUT MOSQUITO CONTROL}

Most people dislike mosquitoes and are aware of the diseases and discomfort that they cause (fig. 1). While a minority of growers accepts mosquito problems as a part of rural life, there are many excellent reasons why everyone should pitch in to minimize mosquito problems in their area.

First, mosquitoes carry diseases to people. Your family, neighbors, and employees are particularly susceptible to mosquito-borne diseases because farming operations may create places where mosquitoes can breed and live. West Nile virus and other types of mosquito-borne viruses are present in California (see sidebar). These viruses can cause infections that may be fatal or lead to permanent brain damage. Other serious mosquito-borne diseases such as malaria and dengue fever are introduced into the state periodically by travelers. Keeping mosquito populations under control helps keep these diseases from becoming established.

Second, mosquitoes threaten livestock and pets. Animals tormented by mosquitoes do not feed properly. If attacked by mosquitoes, cows give less milk, and beef cattle, sheep, and poultry may suffer losses in weight. Mosquitoes may transmit viruses that cause encephalitis in horses. Horses infected by West Nile virus have over a 30 percent chance of dying or becoming disabled. Mosquitoes also transmit dog heartworm and can also carry the virus that causes myxomytosis in rabbits. See your veterinarian to get your animals protected against these diseases.

Third, mosquito problems can decrease property values and cause labor problems. Areas infested with mosquitoes are less desirable places to live and work. Farmworkers may refuse to work if a serious mosquito problem exists. Homeowners

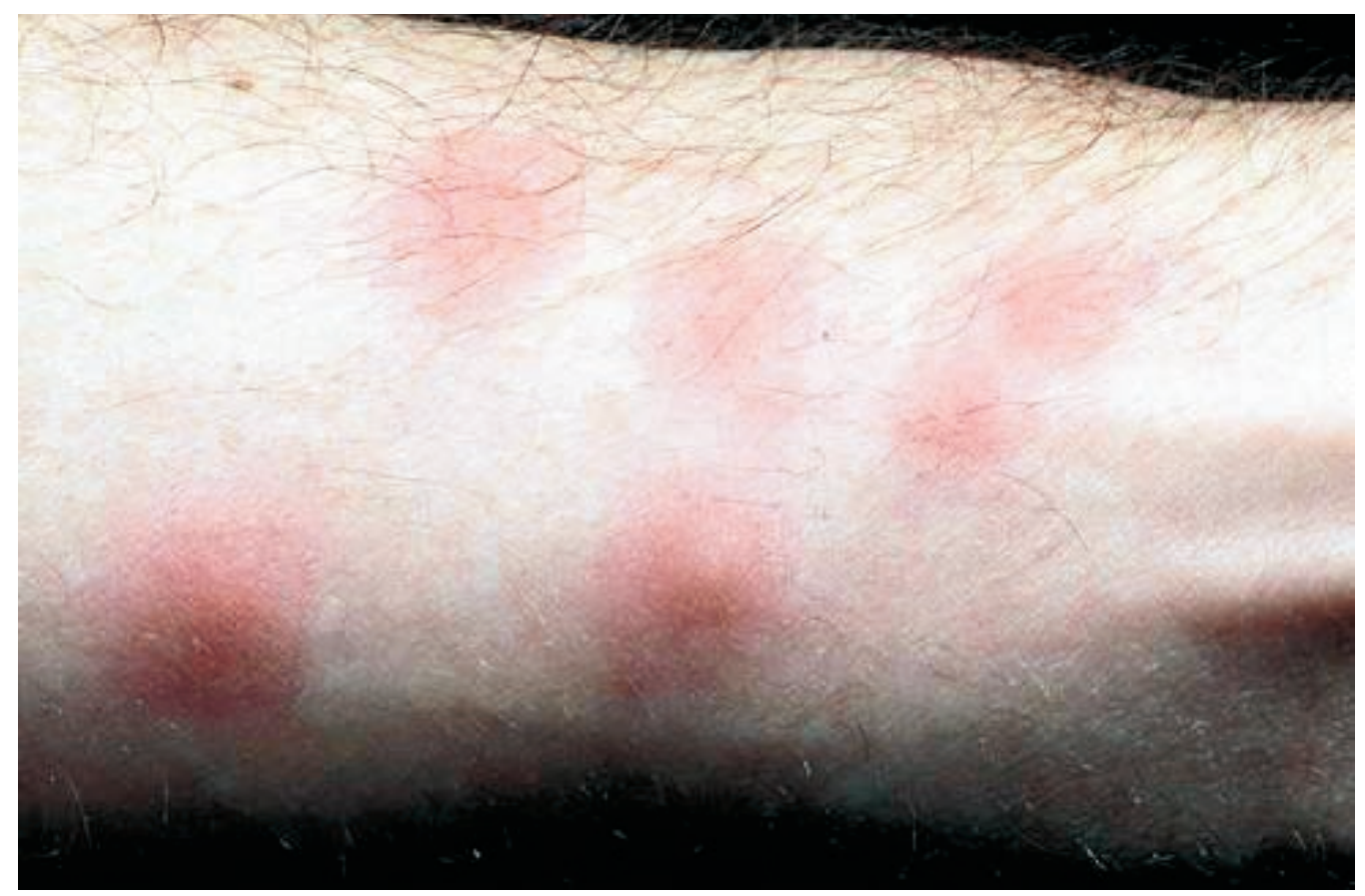

Figure 1. A bumper crop. Photo by Chet. K. Fukushima. 


\section{WEST NILE VIRUS}

\section{What Is It?}

West Nile virus is a virus carried by mosquitoes. Viruses are tiny microorganisms (smaller than bacteria) that inject their genes into cells. The infected cells produce more viruses. Antibiotics are not effective against viruses.

About 80 percent of human West Nile virus infections are so mild that there are no symptoms. About 20 percent of infected people experience West Nile fever, which produces flu-like symptoms (headache, nausea, fever, and sometimes a rash or swollen glands). However, one-half percent of those infected may experience life-threatening or disabling consequences including severe fever and headache, disorientation, paralysis, numbness, convulsions, vision loss, coma, or death. People with severe symptoms should seek medical care immediately. Persons over 50 years of age or those with compromised immune systems are at higher risk of complications.

\section{How Is It Transmitted?}

The virus is mainly transmitted by mosquitoes in the genus Culex, but other kinds of mosquitoes may transmit it as well. The primary life cycle of this virus is between birds and mosquitoes. Birds can produce high levels of the virus in their blood, and mosquitoes pick up the virus when they and their families and guests find it difficult to enjoy barbecues, ball games, gardening, or other outdoor activities when plagued by mosquitoes.

\section{YOU MAY BE RAISING THE MOSQUITO THAT IS BITING YOU! MOSQUITO PREVENTION}

If you minimize mosquito production on your farm, you protect your family, friends, and employees from disease and keep your livestock healthy. You can't grow crops or livestock without water. You can't grow mosquitoes without water, either-all young mosquitoes hatch and develop in water before they mature into flying insects (fig. 2). Although some areas experience problems with mosquitoes flying in from longer distances, locally grown mosquitoes usually cause the most problems. Many mosquitoes stay in the general area where they matured, especially if there is water and animals to feed upon.

\section{Water}

Mosquitoes breed in standing water, that is, any body of water without turbulent flow. They do best in weedy ponds and stagnant water that collects in ditches, fields, or containers, and they require water for just 4 to 14 days to mature (but sometimes longer in cold weather).

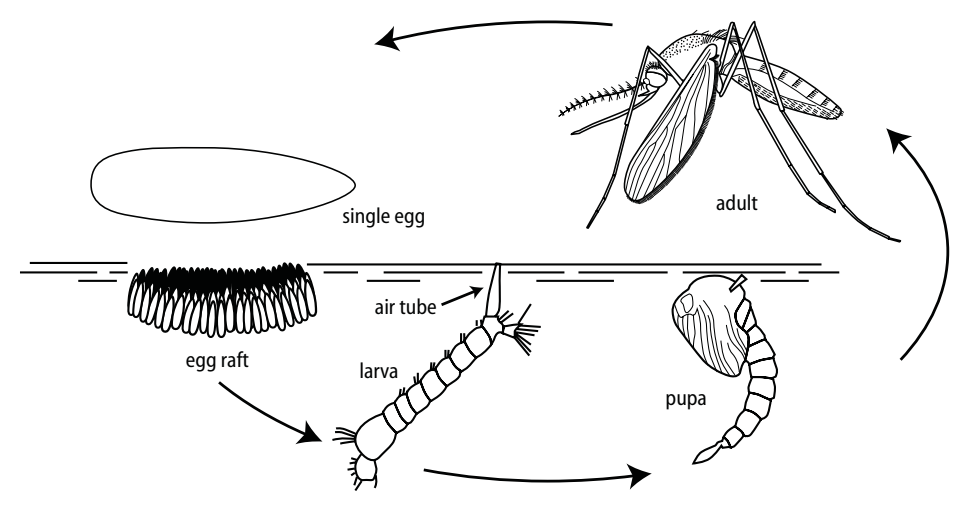

Figure 2. The mosquito life cycle. Egg rafts are typically dark and smaller than a pinhead. Larvae and pupae are about the size of a grain of rice, or slightly larger.

\section{THREE BASIC PRINCIPLES OF MOSQUITO PREVENTION}

- Prevent or eliminate any wastewater that stands for longer than 4 days. This includes water in ruts or unnecessary containers.

- Keep weeds down around ponds, in ditches, and in shallow wetlands.

- Irrigate properly so that all surface water is gone within 4 days.

- Biological and chemical control of mosquitoes can supplement these essential preventative measures.

You can gain some personal protection by wearing long trousers, long sleeves, and using repellant. DEET-based repellants are very effective but it is important to follow the label directions to ensure safe and successful use. To protect the home, make sure that screens are intact and doors are kept closed. Minimize outdoor activity during dawn and dusk, the peak periods of mosquito biting.

The remainder of this publication gives advice for specific situations, discusses biological and chemical control of mosquitoes, and describes common mosquito species. Your local mosquito abatement district or mosquito and vector control district (MVCD) can also help you address specific problems. Consult them on which methods of supplemental control are most effective against the mosquitoes in your area. 
feed. Mosquitoes that feed on infected birds can transmit the virus to humans, horses, and other mammals.

During the brief period that the virus is circulating in the human bloodstream, it is possible (but rare) for it to be transmitted from human to human through blood transfusions, organ transplants, or even breast feeding of infants. In California, the blood supply and organ donations are now screened for West Nile virus, and the risk of infection from these sources is very low. Nursing mothers who think they have symptoms of West Nile fever should talk to their physicians. The virus is not transmitted through casual contact, such as touching, kissing, and coughing.

It is unlikely that mosquitoes would carry the virus from horses to humans or between horses, because the level of virus in mammal blood is too low. Therefore, euthanizing infected horses does not prevent the spread of the disease.

\section{Who Is at Risk?}

Anyone suffering mosquito bites is at risk of this disease.

\section{What Animals Are at Risk?}

Horses and wild birds are the animals that are most susceptible to the virus. Fortunately, domestic poultry and livestock other than horses very rarely show symptoms of infection. One-third of infected horses show severe symptoms and either die or are euthanized. A vaccine is available for horses. Vaccines against other encephalitis viruses do not work against West Nile virus.

\section{NATURAL WATERS ASSOCIATED WITH FARMS}

Growers and dairy operators often serve as stewards of natural waters because ponds, streams, and other wetlands can occur on farmland. Natural waters support a variety of animals including ducks, fishes, amphibians, dragonflies, and fairy shrimp. Managing mosquitoes in extensive wetlands is beyond the scope of this publication (see Managing Mosquitoes in Surface-Flow Constructed Treatment Wetlands, ANR Publication 8117, http://anrcatalog.ucdavis.edu/pdf/8117.pdf). This section supplies a few principles of mosquito prevention that are useful in most natural waters.

Permanent, clean natural waters produce relatively few mosquitoes because these have good populations of predatory insects and/or fish. However, significant mosquito problems can occur in waters that are very weedy and shallow, especially if they receive fertilizers or manure. Therefore, such runoff should be prevented through proper irrigation drainage, conservative use of fertilizers, and creating buffer areas between fields and wetlands.

Unlike stagnant waters created by farming activities, it is undesirable and usually illegal to drain, fill, or substantially reconfigure natural wetlands, and some wetland vegetation is also protected. Private citizens may not introduce fish into natural waters. Changes can sometimes be made under state or federal permits. Consult your local MVCD about what changes are needed and permitted. Several kinds of alterations reduce mosquito problems. Weed control allows natural predators to hunt mosquito larvae more effectively. For example, thin rushes and cattails annually and remove old leaves. Shallow, temporary wetlands can be mowed when dry. If you have a stream on your property that forms isolated, stagnant pools, connect the pools to the main channel with small ditches. This allows predatory insects and fish to find and eat mosquitoes and can aid stream flow, which drowns mosquitoes.

Some coastal farms have tidal areas that produce mosquitoes when flooded by the tides or rain. Manage this problem by constructing and maintaining ditches that drain off the water when the tide falls. You may need to add a levee with a tide gate to reduce or prevent salt water from entering during high tide, while allowing fresh water to flow out at low tide. MVCDs may use insecticides to control marsh mosquitoes, but this can become costly in extensive areas of marsh. In such cases, physical control is preferable unless the presence of endangered species or other concerns prevent land reconfiguration.

\section{MANAGING STAGNANT WATERS CREATED BY AGRICULTURAL ACTIVITIES}

\section{Impoundments}

Impounded water can be a source of mosquitoes, but a few simple approaches will help reduce mosquito breeding sites. For example, a reservoir will not produce mosquitoes if its sides and bottom are properly graded, there is little emergent vegetation, and it is stocked with insecteating fish. In general, a steep-sided pond of at least 3 feet $(1 \mathrm{~m})$ in depth (to cover bottom-growing weeds) offers the least problem. Destroy weeds around the margin of the pond to help eliminate hiding places for larvae. Maintain a stable water level to minimize the area where floodwater mos- 
quitoes can lay their eggs. Equip water sources with float valves to maintain the water level.

\section{Miscellaneous Breeding Habitats}

Many items create areas where mosquitoes can breed: leaky irrigation piping, old tires, birdbaths, tarps that form puddles, clogged gutters, paint cans, boats or wheelbarrows stored upright, open garbage cans and lids, and pet food bowls. Inspect your property and fix, clean up, invert, puncture, or regularly flush out any of these potential problem areas. Because they typically contain few or no predators, each of these small habitats can produce hundreds of biting mosquitoes.

\section{Poorly Maintained Cesspools and Septic Tanks}

Septic systems can produce droves of mosquitoes. A properly constructed and maintained cesspool or septic tank should have an adequate soakage pit, cover, vent, and overflow outlet. Check your local health department requirements.

\section{Road Ruts and Potholes}

Even relatively small road ruts and potholes can produce mosquitoes if water stands in them during in warmer weather, because these waters contain few predators.

\section{Treeholes}

Rain water that accumulates in treeholes (fig. 3) can provide an ideal place for the western treehole mosquito to develop its larvae, usually in winter and spring. This mosquito carries dog heartworm, and dogs should be protected against this serious disease. Treeholes can occur in old orchard and landscape trees as well as in wild trees.

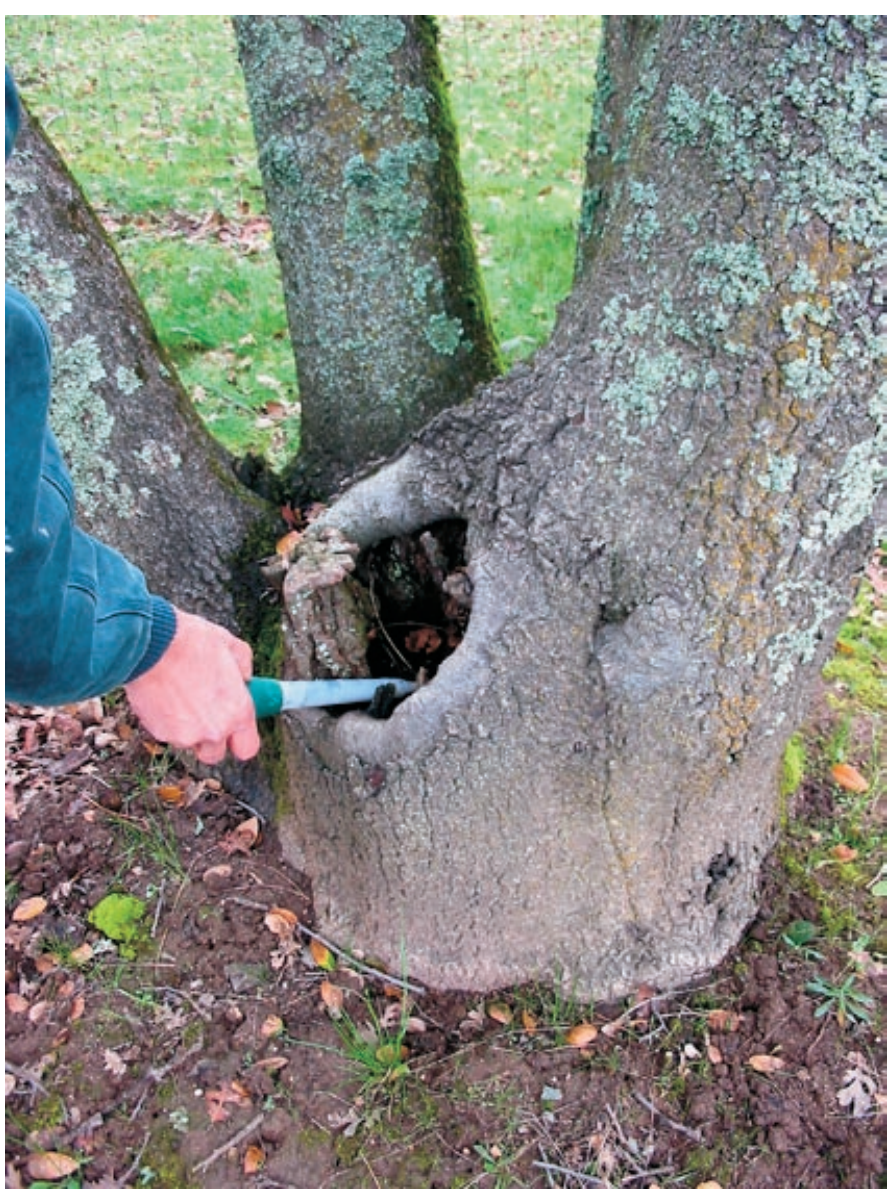

Figure 3. Treeholes like this one may provide habitat for mosquitoes. Photo by Jamesina Scott. Holes may be caused by rot, fire injury, or from pruning that leaves a hollow at the center of the tree. Fill treeholes with cement or other substances. Keep in mind that treeholes may provide bird nesting habitat during the drier months; it may be preferable to drill drains from the base of the treehole to the outside and remove debris that clogs the holes. Consult an arborist about treeholes in valuable or potentially hazardous trees. Methoprene pellets added to holes prevent mosquitoes from maturing (see the section "Chemical Control," below); add these before the holes fill or anytime before the mosquitoes pupate and renew them annually.

\section{Livestock Watering Ponds}

Ponds and natural pools that livestock drink from may become serious mosquito-breeding areas. Animal waste adds nutrients to the water that benefit mosquitoes, and hoofprints create puddles where mosquitoes may be isolated from predators. If feasible, fence ponds along the edge to create a single access area. This keeps the animals from trampling the entire edge, although if too much room is left between the pond and fence, animals may still create ruts. Paving the access point can reduce puddles, but be sure to provide good footing for the animals. Weed control reduces hiding places for mosquitoes. It may be necessary to treat these ponds regularly with a biological larvicide or to introduce insect-eating fish if they are not already present. However, do not introduce fish unless the pond is man-made and isolated from natural waters. 


\section{Watering Troughs}

Troughs and other containers that provide water for animals can easily become a source of mosquitoes. The ground surface around the troughs often becomes roughened by animal hooves, producing hundreds of small water pockets. Permanently correct this potential source of mosquitoes by providing drainage or paving the area. Temporary improvement can be had by flushing out the water every week if drainage outside the trough area is good, or by treating the water with a biological larvicide. Do not add chemical insecticide to water that livestock may drink. Clean cattle tanks and watering troughs regularly to prevent mosquitoes from multiplying. Mosquitofish may also be added to provide control. Remove or destroy troughs or tanks that are not in active use.

\section{IRRIGATED FIELDS FOR UPLAND CROPS}

Good agriculture results from the efficient use of water, and efficient use of water reduces mosquito populations. The larval and pupal stages of all mosquitoes require water for their development. It is here that you can break their life cycle most effectively.

Fortunately, the irrigation practices that are best for upland crops do not generally produce mosquitoes. Most crops thrive when water remains on the surface for no more than 12 hours, but even the most rapidly developing mosquito species need 4 days in water to reach the adult stage. Fields may be irrigated without creating mosquito breeding sites by using either flooding or sprinklers as long as the fields are properly graded and do not hold water longer than 4 days. Water standing on fields for excessive periods of time reduces crop yields, encourages the growth of weeds, presents an unhealthy environment for livestock, and may decrease soil quality, in addition to producing mosquitoes.

Increase the efficiency of irrigation on your farm and at the same time decrease your mosquito problem by following three rules of water management:

- Prepare the land so that slopes are uniform and drainage is good.

- Inspect and correct areas with poor drainage.

- Do not overirrigate, as this can create standing water. For example, if you irrigate by flooding it may not be necessary to run the water until it comes out of the bottom check. Running the water until two-thirds of a field is covered may supply enough water to spread to the remaining one-third of the field, although some trial and error may be needed.

\section{Land Preparation}

Proper land preparation for both irrigation and drainage is the key to successful water management. Correctly leveled fields help control mosquitoes and also produce higher yields at less cost. On good slopes you can apply irrigation water more efficiently, lowering costs for water and irrigation labor. On these slopes you can grow more uniform crop stands that can be harvested more easily. Laser planing is currently the most effective way of leveling fields.

A field that is properly leveled will have a continuous slope in the direction of the irrigation runs. Slopes of at least 0.2 foot per 100 feet $(6 \mathrm{~cm}$ per $30 \mathrm{~m})$ are desirable for most crops. Where flatter slopes must be used on soils that do not take water readily, extreme care should be taken that no low spots occur in the field. When available, a slope of 0.3 to 0.5 foot per 100 feet ( 9 to $15 \mathrm{~cm}$ per $30 \mathrm{~m}$ ) is preferable on pastures. If possible, level the land so there is a slight side fall across the field. This facilitates the delivery of irrigation water through the field ditches and helps collect wastewater in the lower corner of the field. 
It is the practice in some areas to make the lower sections of the irrigation run perfectly flat, which spreads out excess irrigation water that reaches the end of the field. This is a desirable practice only in areas where the soil takes water readily, and it should not be used on soils where water penetration is slow. Standing water not only causes mosquito problems, it can "drown out" crops in the lower ends of fields. In such cases it is better to increase the slope rather than reduce it and to include a small drainage ditch at the ends of the irrigation runs.

\section{Strip (Border) Checks Versus Contour Checks}

Strip, or border, checks are small levees that create rectangular bays on fields with good slopes. Contour checks are levees that follow the contours on relatively flat land, producing irregularly shaped bays. In general, fields that are irrigated with contour checks are a greater source of mosquitoes than those irrigated with strip checks, because contour checks are used on flatter grounds that are prone to ponding. Also, contour checks are often flooded sequentially, and flows between checks are slow. This allows mosquitoes to continue developing as they move with the irrigation water from check to check. Either kind of check can provide mosquito habitat if water is left in the bay too long, and waterlogging can be a problem if bays are too large relative to the water flow rate.

\section{Strip checks}

Strip checks are usually preferred when minimum slopes are available of 0.25 foot per 100 feet $(7.5 \mathrm{~cm}$ per $30 \mathrm{~m})$ on soils with good vertical drainage, or 0.5 foot per 100 feet $(15 \mathrm{~cm}$ per $30 \mathrm{~m})$ on more impervious soils. The land between the levees should be perfectly cross-leveled so water will spread uniformly as it moves down the field. The slope must be continuous, although it doesn't have to be perfectly uniform.

\section{Contour checks}

Contour checks are most often used where the general slope of the land is less than 0.1 foot per 100 feet $(3 \mathrm{~cm}$ per $30 \mathrm{~m})$. If the slope is greater than this amount, growers generally prefer the strip check method. Contour checks can be used if relatively large heads of water are available, the soil takes water slowly, and the land is fairly flat.

The contour method of irrigation consists of constructing levees on contour lines at vertical intervals of generally 0.2 or 0.3 feet $(6$ to $9 \mathrm{~cm})$. Control gates are placed in the levees to hold the water until the contour basins are irrigated and to serve as a spillway to prevent water from overtopping the levee. The usual practice is to hold the water in each basin until the area is completely flooded and then open the control gates and release the water to the next lower check.

The main difficulty in using this method, for both crop production and mosquito control, is removing the excess water from the field following each irrigation. A small amount of land leveling may be needed to fill in the natural depressions that occur in the field. Corrugations made in the direction of the slope of the land before the levees are constructed help drain the water into the borrow trench. A float is often used to smooth and partially fill these trenches.

To minimize mosquito problems created by wastewater standing in contour checks, many growers use a broad, shallow ditch down the center of the field. This serves as a delivery ditch for the irrigation water and as a drainage ditch for wastewater. Constructing this ditch with a bucket scraper and removing the excavated soil leaves no spillbanks to dam the water. The fields are generally laid out so that ditches occur at intervals of not over 660 feet $(200 \mathrm{~m})$, or so that the drainage water from the field will not have to travel over 330 feet $(100 \mathrm{~m})$ to enter a ditch. Control gates are constructed at the points where the ditch crosses the levees. The crest of the control 
gates is on the same grade as the bottom of the ditch. Flash boards in the gates are used to check the flow of water during irrigations. When the flash boards are removed, the ditch carries off most of the excess water.

\section{Field ditches}

Ditches that hold water for more than 4 days can be a source of mosquitoes. Water can remain in a ditch constructed in heavy soil if the ditch has no drainage outlet, if it is not constructed on a continuous grade, or if it is not properly maintained. Clumps of debris and footprints can create puddles.

A properly constructed head ditch can be maintained more easily than one that is built poorly. You may want to place "ditch pads" along the line where the ditch is to be constructed. This should be done while the land is being leveled. A ditch pad is a mound of earth 8 to 12 inches ( 20 to $30.5 \mathrm{~cm}$ ) high and 10 to 16 feet ( 3 to $5 \mathrm{~m}$ ) wide. The excess earth permits building strong ditches with well-shaped banks. The bottom of the ditch can be maintained near the elevation of the normal ground surface, which permits easy draining of the excess water from the ditch after the irrigation is completed.

You may also try the practice of "plowing in" the field ditches following each irrigation. Plowing in allows cultivation equipment to turn more easliy. You can rebuild the ditches prior to each irrigation. This practice prevents field ditches from becoming mosquito habitat.

Leaky head gate and turnout structures create small pools of standing water. These pools often contribute greatly to mosquito problems. Take care during construction to make sure that water cannot escape around or under these structures and that the gates fit tightly enough to hold the water. Such precautions can often save sufficient water to pay for the cost of the structures.

\section{Drainage}

In many areas, irrigated farms with inadequate drainage produce most of the mosquitoes. "No till" systems typically have poor drainage due to low percolation and soil compaction and need extra care in water management. Surface drains can remove excess water that collects at the lower ends of irrigated fields. It may be impractical to prevent the escape of some irrigation water from the fields. The amount of water wasted may be small, but if ignored it can produce many mosquitoes.

Drainage systems installed in some areas collect wastewater from farms and remove stormwater during rainy periods. The wastewater can often be diverted into canals at lower elevations and reused for irrigating other lands. In areas where drainage outlets are not available, growers may wish to jointly construct a drainage system.

\section{Return flow systems}

Reusing wastewater is one of the most effective means of controlling mosquitoes. It eliminates standing water from the lower end of a field, which is frequently a trouble spot, particularly on irrigated pastures, and it also conserves water. Excess irrigation water is collected in a sump at the low point in the field. A low-lift pump lifts the water into a pipeline that delivers the water back into an irrigation system. The water can be used for irrigating other land close to the sump.

The main expense of a return flow system is for the pump and pipelines. But because of the low lift, power costs to operate the pump are low. This "waste" water is usually good enough for irrigating crops. It often contains fertilizers that can be saved by reusing the water. Also, its warm temperature is favorable to growing crops. 


\section{MOSQUITO-FREE IRRIGATED PASTURES}

Irrigated pastures often create an environment favorable for mosquitoes, especially floodwater mosquitoes. Pastures are often put on shallow, poorly drained soils, or on heavy basin soils that normally occur where the land is relatively flat and difficult to drain. Many irrigated pasture plants are shallow rooted and require frequent irrigations. Because pasture drainage is often poor, take care to prevent pastures from becoming a source of mosquitoes. Luckily, the same practices that are likely to increase the production of pasture feed also help eliminate mosquitoes.

- Have the land properly graded for irrigation and drainage before planting the forage crop. Without proper grading, irrigations may be less effective and mosquito problems are more likely.

- Apply only enough water to wet the soil to the depth of rooting. Otherwise, nutrients will be leached from the soil, water will be wasted, and standing water will be more likely.

- Irrigate only as frequently as is needed to maintain proper soil moisture. Check soil moisture regularly until you know how your pasture "behaves."

- Drain excess water from the pasture within 24 hours following each irrigation. This prevents "scalding" and reduces the number of weeds in the pasture. Good check slopes are needed to achieve drainage. A drainage ditch can remove the water from the lower end.

- Inspect fields for drainage and broken checks periodically to see whether releveling or reconstruction of levees is needed. Small areas that hold water can be filled and replanted by hand. Broken checks create cross-leakage that provide habitat for mosquitoes.

- Keep animals off the pasture while the soil is soft. An ideal mosquito habitat is created in irrigated pastures when water collects in hoofprints of livestock that were run on wet fields or left in the field during irrigation (fig. 4). Keeping animals off wet fields until soils stiffen also protects the roots of the forage crop and prevents soil compaction that interferes with plant growth.

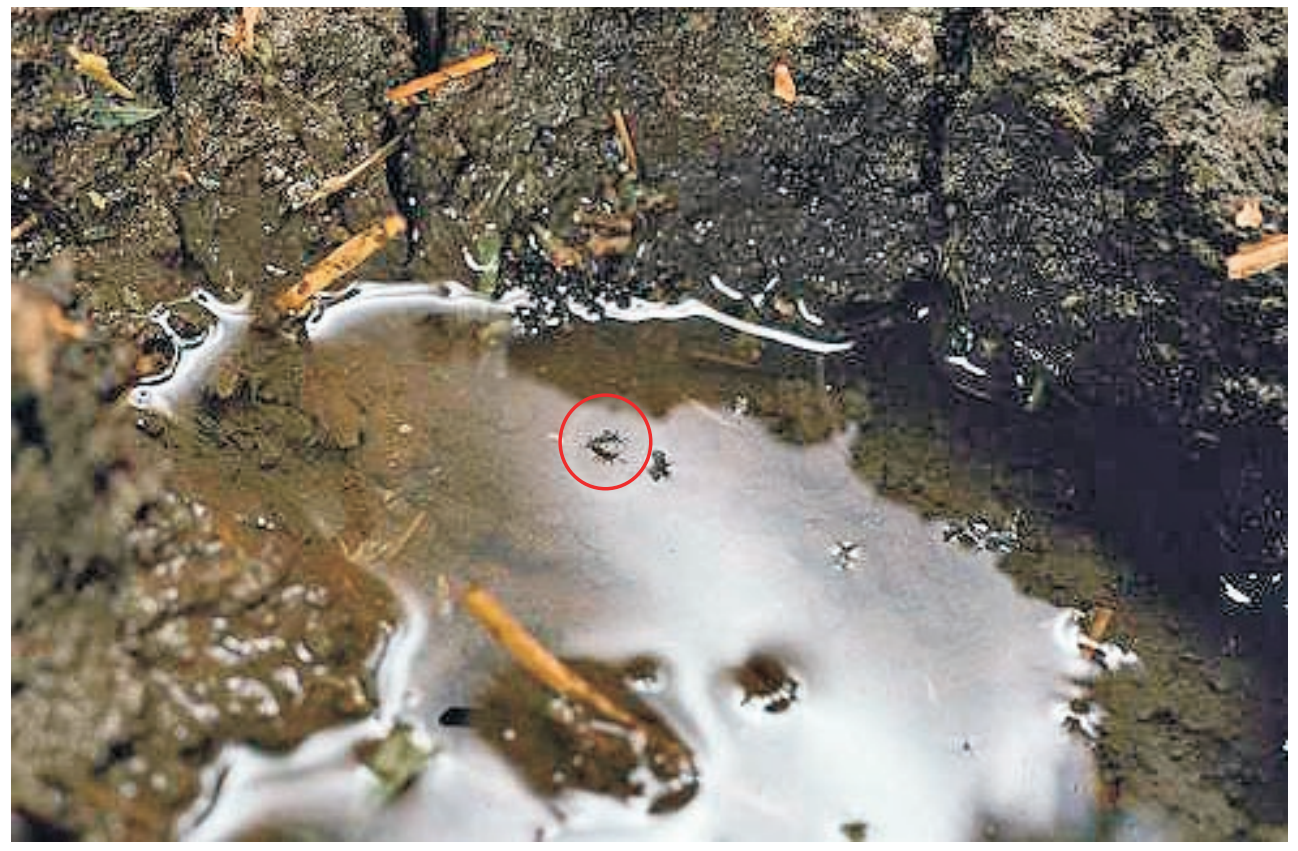

Figure 4. A mosquito (circled) emerges from a water-filled hoofprint caused by putting livestock on a wet pasture. Photo by Robert K. Washino.
- Rotate fields. Break up your pasture into a number of smaller fields so that the animals can be rotated from one field to another. This allows fields to dry between irrigations and provides a sufficient growth period between grazings. It also prevents hoof damage, increases production from irrigated pastures, and helps improve water penetration into the soil by promoting a better root system.

- Do not overfertilize. Excess fertilizers can leach into irrigation tailwater, making mosquito production more likely in ditches or further downstream. 


\section{RICE}

Over one-half million acres (200,000 ha) of rice are currently grown in California. The standing water of rice fields and associated irrigation structures produces a great challenge for mosquito control (fig. 5). The majority of mosquitoes in rice fields are Culex tarsalis in the summer and Anopheles freeborni from August through when the fields are drained. Culex tarsalis is the vector of encephalitis viruses, including West Nile virus, and Anopheles freeborni can carry malaria, although this disease is now rare in the state. Some fields may also produce floodwater mosquitoes (Ochlerotatus melanimon) within the first 1 to 3 weeks of flooding. Some MVCDs set up regular inspection and treatment visits for rice fields. They often add mosquitofish to fields and may control mosquitoes with biological or chemical agents as well (see the section "Biological and Chemical Mosquito Control," below).

Grower practices can affect the numbers of mosquitoes produced in rice fields. The following sections describe how you can manage various aspects of rice cultivation to minimize mosquito production and help MVCDs work most efficiently.

\section{Basin Shape}

Mosquito larvae find refuge from predators in shallow waters and grassy areas. Reduce mosquito breeding areas by configuring your fields, field edges, levees, and irrigation ditches so that they drop rapidly into deep water. Eliminate shallow edges and any small seepage puddles near levees and fix leaky water control structures to prevent isolated puddles.

\section{Fertilizing}

Overfertilizing can cause algal blooms. When algal mats rise to the surface they create isolated pockets of surface water where mosquito larvae are protected from predators. Incorporate fertilizers several inches into the soil to reduce algal blooms. Reducing algae also helps improve yield by reducing competition between rice and algae.

\section{Flood-up}

Floodwater mosquitoes (Ochlerotatus melanimon) can breed in rice fields. These mosquitoes appear within a day or two of flood-up and can occur in very large numbers. Check with

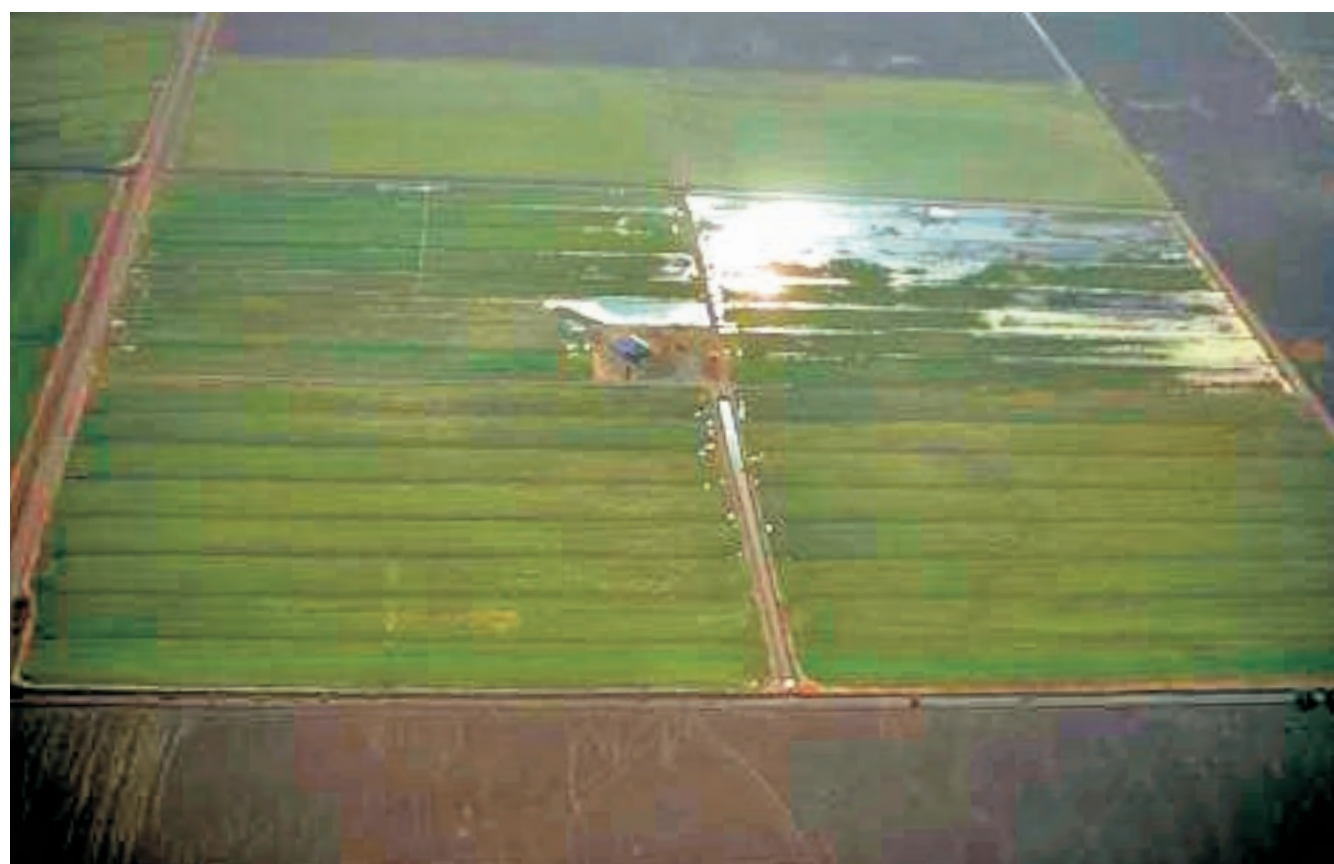

Figure 5. Standing water in irrigated rice presents a great challenge for mosquito control. Photo by Robert K. Washino. your local MVCD to see whether these mosquitoes are a problem in rice in your area; if so, alert the MVCD when you begin flooding. Rapid flooding of the fields encourages mosquito eggs to hatch in synchrony, allowing MVCDs to eliminate most larvae with one treatment.

\section{Weeds}

Weedy fields and levee edges can provide shelter for mosquito larvae. Predators hunt less efficiently in dense weeds, so good weed control practices help control mosquitoes. However, many her- 
bicides are oily and will suffocate air-breathing predaceous insects that provide some natural mosquito control, and some herbicides have direct toxicity to insects as well.

Herbicides are best used early in the season so that the predators are not reduced when the water is warmer and mosquitoes develop faster. Predator-friendly weed control methods include deeper flooding early in the growing season, weed removal along levees, and crop rotation to upland crops every few years.

\section{Pesticides}

Some pesticides kill both mosquitoes and their predators, but since mosquitoes have shorter generation times, they typically recover faster than the predators. This may lead to an increase in mosquitoes. Some pesticides can kill mosquitofish, especially pyrethroids (e.g., lambda-cyhalothrin, or Warrior and Karate). Advise MVCDs if you use pesticides after fish have been introduced to the fields so they can add more fish if needed. MVCDs typically introduce fish within several weeks after flooding.

\section{Draw-downs and Draining Rice Fields}

Water may be drawn down or drained from rice fields during the growing season for weed control. While mosquitoes can't breed in a dry field, reflooding can lead to a mosquito problem for several reasons. Draining removes most of the predators from the field, increasing the chance of mosquito resurgence after reflooding. Culex spp. mosquito females find newly flooded fields attractive for egg laying. Reflooded fields may also produce the floodwater mosquito.

Advise MVCDs if you need to drain and reflood a field midseason so they don't waste inspection trips when fields are dry and so they can resume inspections in time to prevent mosquito emergence. They may also need to restock mosquitofish.

Draining fields at the end of the growing season does not usually generate a mosquito problem because remaining predators tend to concentrate in residual water. Nevertheless, well-graded and even-draining fields, borrow pits, and ditches help reduce mosquito numbers because some areas may lack predators. Rice fields can also produce mosquitoes in the fall if they are reflooded for straw decomposition and to create wildlife habitat. Fields should be reflooded as late as possible because mosquito reproduction decreases in cold weather.

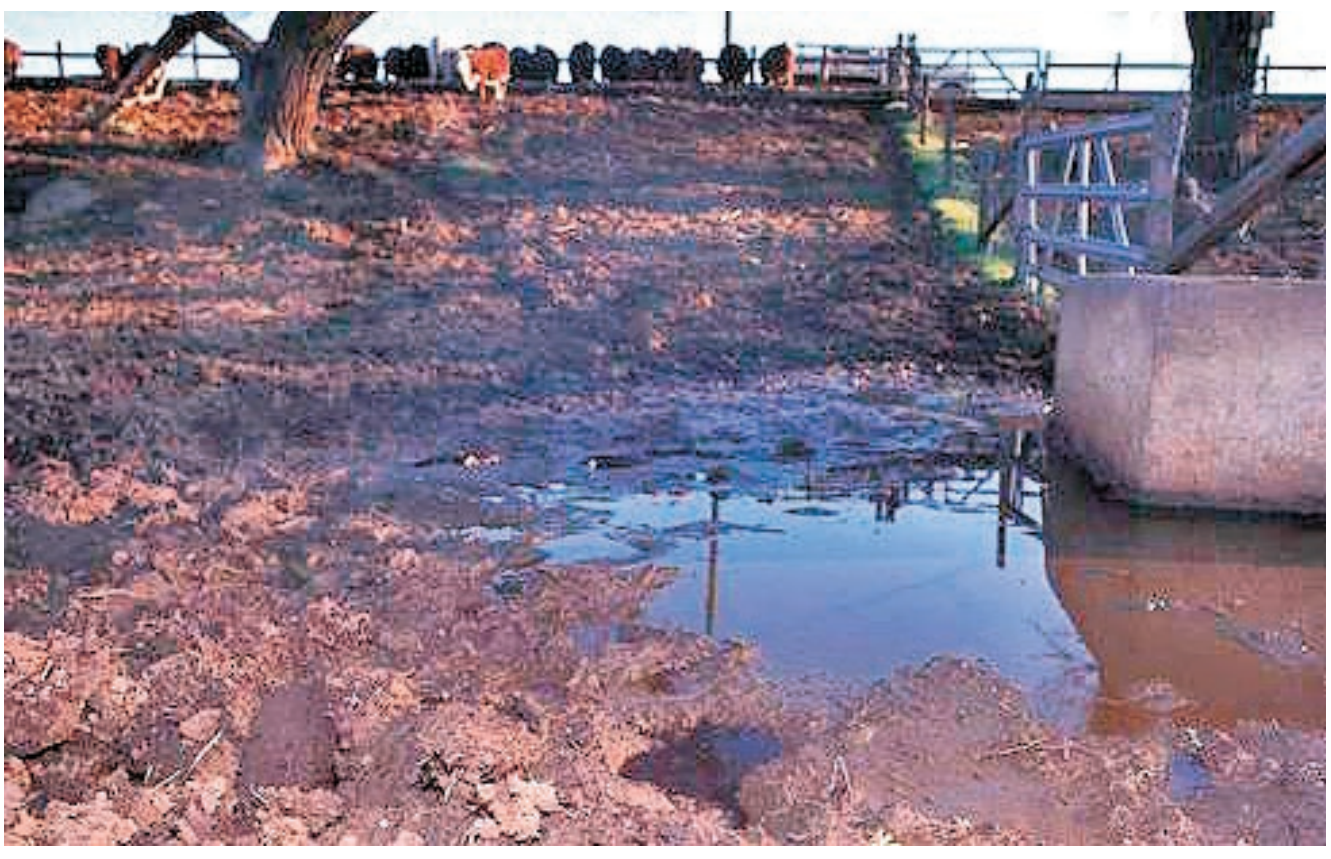

Figure 6. Mosquitoes can breed in poorly drained dairies. Photo by Robert K. Washino.

\section{DAIRY OPERATIONS}

Dairy wastes can breed hordes of mosquitoes. Dairies face wastewater management challenges on a large scale. A full description of dairy construction is beyond the scope of this publication, but the tips in this section can help minimize mosquito production.

Drain the liquids from a dairy and store them properly or use them for irrigation (fig. 6). By law, dairy drainage must not percolate into groundwater or contaminate surface water. If you grow crops (including forage 
crops), an excellent method of eliminating a source of mosquitoes is to store the nutrient-rich liquid in a dairy lagoon for use in an irrigation system. Using liquid manure can yield great savings in fertilizer costs.

Barns and pens should be surfaced with concrete and sloped to a drain at a slope of 2 to 3 percent ( $1 / 4$ to $3 / 8$ inch per foot, or 2 to 3 centimeters per meter). Pipe washwater and liquid manure to a separator and then a holding lagoon. Corrals and other earthen outdoor work areas should be graded at least 3 percent and configured according to an overall drainage plan for the facility. This avoids ponding of wastes and rainwater. Regrade as needed to eliminate ponding and muddy areas. Ideally, the corrals and milking parlor should be at the highest elevations and the lagoon at the lowest. You can also minimize disease risks if you provide good drainage and flushing and locate holding basins at low spots, away from animals.

Liquid manure should first be run through a mechanical separator, a small separator pond, or other separation structure (apron, sump, or basin) to remove solids. Solids form floating mats that shelter mosquitoes and allow weed overgrowth. Excess fiber also blocks pipelines and can foul crop plants. Separated solids can be spread and dried to eliminate fly production. It is wise to have a backup system for mechanical separators, which occasionally break down. Separator ponds should be relatively narrow, no more than 60 feet $(18 \mathrm{~m})$ across. A narrow pond with a good road along it allows the application of mosquito control agents to the entire surface if necessary. Crusts of solids can cause problems if they form water-holding cracks where mosquitoes and flies breed in great numbers. Crusts can also prevent insecticides from killing mosquito larvae. Ponds can be agitated with water and pumped out if solids start crusting over. Compost removed solids or spread them thin to dry. Like all artificial ponds, the separator pond should be steep sided, and weeds should be controlled around its edges. Manage other separating structures so that no water stands for more than 4 days.

Properly constructed dairy lagoons can minimize mosquito problems. Like separator ponds, lagoons should be steep sided and weeds should be controlled around the edges. Use an agitating pump or a solids filter to prevent the formation of loose surface crusts and algal mats. Depending on the landscape, wide lagoons, greater than 100 feet $(30 \mathrm{~m})$ in diameter, may be subject to wind action that provides some natural control of crusting. However, if this does not occur, use narrower lagoons so that insecticide sprays can reach the whole surface. The storage volume should be 15 cubic feet $(0.42$ cubic meter) per cow per nonirrigation day. This volume prevents overflow during the rainy season.

Drawing off the water regularly for irrigations can help control mosquitoes, but it is essential not to overirrigate, which moves the mosquito problem into the fields. If possible, refill lagoons and keep them at a stable level after irrigations to minimize weed growth along edges. Lagoons should be kept shallow only close to the onset of the rainy season in order to prevent flooding.

Finally, provide a good access road around the lagoon for maintenance, weed control, and for occasional mosquito larvicide applications, if necessary.

Mosquito abatement personnel have the legal authority to inspect and treat properties that breed mosquitoes. To guard against the movement of livestock diseases among dairies, provide truck and boot decontamination areas near the entrance to your facility. If possible, you may want to provide an access road to holding and separation ponds that does not require travel past animal pens. Contact your local MVCD to request that their technicians take the proper precautions.

\section{BIOLOGICAL AND CHEMICAL MOSQUITO CONTROL}

Control of mosquitoes by applying biological or chemical treatments is a supplement to the preventive measures of good water and weed management. It does not replace 
them. Prevention is key because the need to use biological or chemical treatments may be overlooked until it is too late, or the treatments may not be effective for various reasons. Reducing mosquito habitat reduces the production of mosquitoes.

MVCD personnel may use biological or chemical controls on mosquitoes.

Pesticide applicators need special permits to apply insecticides for mosquito control in California, so you will usually need to work with MVCDs to control mosquitoes using insecticides. This section discusses substances commonly used against larval or adult mosquitoes. Visit the California Department of Pesticide Regulation Product/Label Database Web site (http://www.cdpr.ca.gov/docs/label/labelque.htm) for further information on specific pesticide formulations. Insecticide formulations change frequently as methods are improved.

\section{Control of Larvae and Pupae}

Mosquito larvae can be controlled by substances added directly to the water. These substances may be organisms that consume them, biological compounds that poison them or cause fatal infections that are specific to them, chemicals that disrupt their development or physiology, or oils and films that suffocate them. Biological compounds tend to be more expensive than chemical controls but they affect fewer nontarget organisms. Conserving nontarget organisms helps maintain natural control of mosquitoes by predators that eat mosquito larvae, such as water bugs, dragonflies, and backswimmers (fig. 7).

\section{Biological Control}

\section{Mosquitofish}

The mosquitofish (Gambusia affinis) is a small top-feeding minnow that is often used in mosquito control. The mosquitofish is not native to California but is now found in many waterways due to introductions for mosquito control or escapes. It is not legal for private citizens to introduce fish into natural waters of California, but mosquitofish may be used in tanks, containers, or artificial ponds. Do not stock areas that could connect to natural waters during floods. The mosquitofish is most effective in waters that are not too weedy, because in weedy areas they may harm other predators more than mosquitoes. Mosquitofish are not appropriate in vernal pools because many vernal pool invertebrates
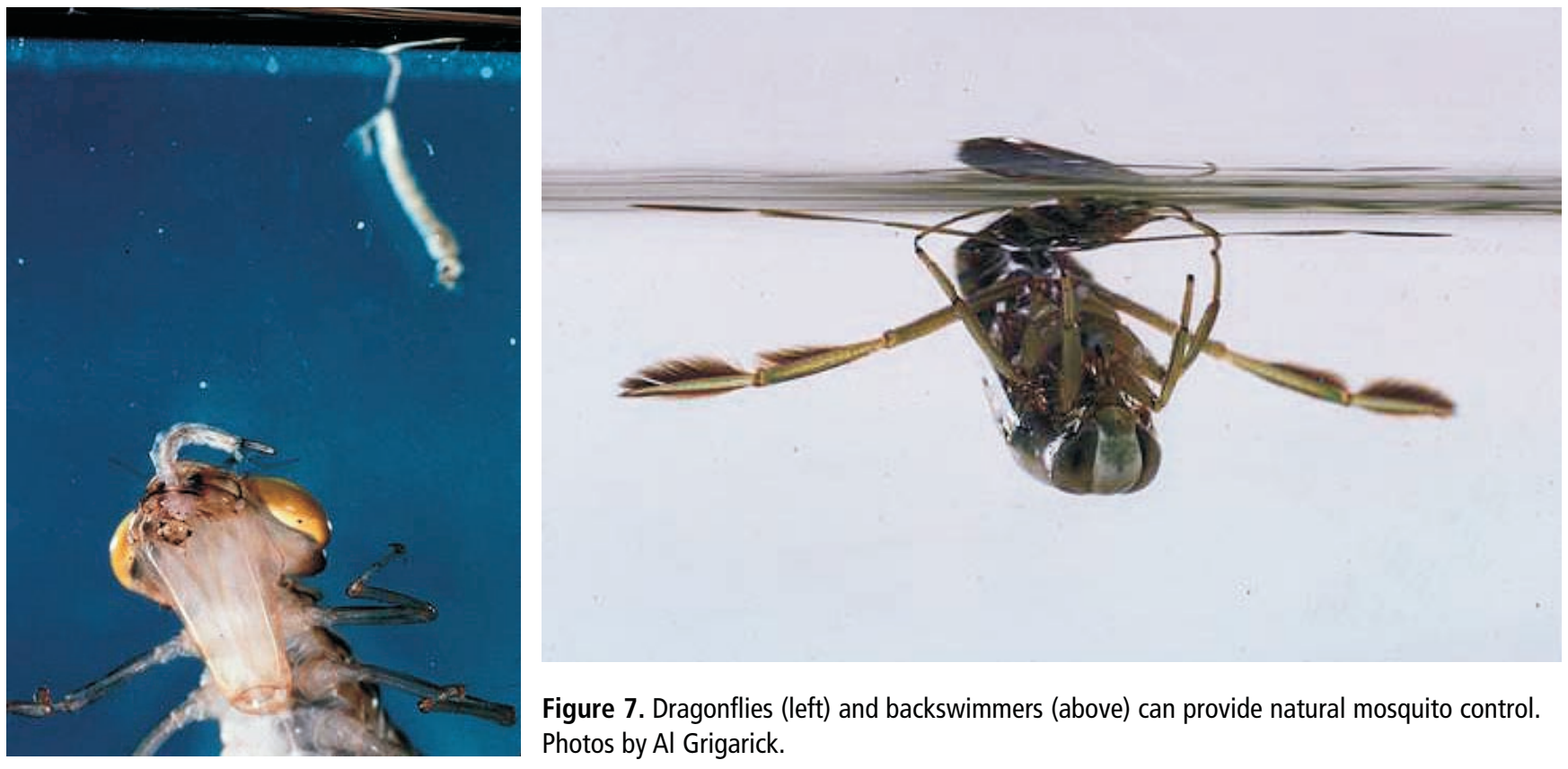

Figure 7. Dragonflies (left) and backswimmers (above) can provide natural mosquito control. Photos by Al Grigarick. 
and other species do not have defenses against fish. Contact your local MVCD if you think you have a situation that is appropriate for mosquitofish.

\section{Bacteria}

One commonly used biological control is the bacterium Bacillus thuringiensis israelensis (Bti). This bacterium contains a toxin that is activated by the mosquito gut. Bti is toxic to mosquitoes and a limited number of other flies, including blackflies and some midges. It is manufactured as a noninfectious bacterial concentrate. Formulations include a sprayable liquid, granules that can sift through vegetation, and as floating briquettes for mosquito control in small bodies of water. Bti kills mosquitoes over the course of a few days (liquid or granules) or up to 3 weeks (floats). It is often available at garden stores. One limitation of Bti is that it is not effective against mosquito pupae or larvae near pupation, because pupating mosquitoes do not feed and may not ingest a lethal dose.

Another bacterium, Bacillus sphaericus (Bs), is also toxic to mosquitoes. Bs is sold as a living form that can cause infections in mosquitoes. This bacterium is most effective against mosquitoes in the genus Culex, and it also affects some Anopheles, Ochlerotatus, and Psorophora spp. mosquitoes. It is not effective against several species of mosquitoes, so you must know the species of mosquito present for effective use. Bs is safe for nontarget organisms, but it is not effective against mosquito pupae. It can kill mosquitoes for up to several weeks, depending on the amount used.

\section{Other biological controls}

Some fungi, nematodes, and copepods (freshwater crustaceans) are also effective against mosquitoes, but these are not widely produced commercially.

\section{Chemical Control}

Chemical controls are typically very effective against mosquitoes. However, if the same chemicals are used against many generations of mosquitoes over a large area, the mosquitoes may develop resistance. This happens because some mosquitoes have genes that make them less sensitive to the toxin. These mosquitoes survive the treatment and gradually create a resistant population that cannot be controlled with the same chemical. Rotating the classes of chemicals used to control mosquitoes prevents resistant populations from building up, because mosquitoes with resistant genes are less likely to survive different treatments in different years. It is very important to prevent the emergence of resistant mosquitoes, because chemical control is a strong defense against serious mosquito-borne diseases such as West Nile fever and malaria.

\section{Insect growth regulators}

Some chemical agents mimic natural substances that regulate insect development, preventing mosquitoes from maturing. Methoprene is a commonly used insect growth regulator. It can be applied as a liquid, which kills a single batch of mosquitoes, or as pellets or briquettes that can give control for 30 days or several months, respectively. Methoprene does not kill mosquito larvae immediately; it kills them as they begin to transform into adults. It may affect a few other insects, such as midge larvae, and possibly some crustaceans, but it is safe for other forms of life at rates used in mosquito control. Insect growth regulators have the advantage of not killing insects immediately so that they are available as prey in the food chain.

As with biological controls, methoprene does not work against pupating mosquitoes. One concern with the pellet and briquette forms of methoprene is that they may cause resistance in mosquitoes because they persist for so long. They should be used in limited areas or rotated with other control methods. 


\section{Oils and monomolecular films}

Mosquito larvae need to breathe air to live. Oils suffocate virtually all species of mosquito larvae and pupae by forming a barrier at the water's surface. In the past, diesel oil was used, but this is unsightly and toxic to many aquatic animals and some plants. The oil that is currently used, Golden Bear Oil, is less toxic and persists in the environment for just a few days. Golden Bear Oil is the only material available in California that is very effective against mosquito pupae. Oil drowns any aquatic insects that need to breathe air, including mosquitoes, diving beetles, and many bugs. Air-breathing insects are important natural predators of mosquitoes, so this product can temporarily disrupt biological control. To preserve predators, it is important to control mosquitoes by other methods before they reach the pupal stage. However, oil is a necessary tool in cases when mosquitoes have already pupated by the time they are discovered.

Oil causes bird feathers to mat, and matted feathers cannot keep young birds warm and dry. Therefore, oil should be avoided or used sparingly if young birds are present and the weather is cold.

Monomolecular films are nontoxic surfactants that act by either coating the mosquito's breathing tube (siphon) or causing the siphon to flood. Agnique and Arosurf are currently available brands. Like oils, these can be effective against both larvae and pupae, but they also drown some beneficial insects. Holes may form in the film on windy days or around vegetation, providing refuges where mosquitoes can survive. The effectiveness of this method should be closely evaluated especially in vegetated areas or on windy days.

\section{Control of Adult Mosquitoes}

\section{Biological control}

Unfortunately, there are at present no effective biological controls for adult mosquitoes. Bats, swallows, dragonflies, and damselflies consume adult mosquitoes, but they do not reduce mosquito populations enough to break disease cycles or significantly reduce annoyance by large populations of mosquitoes. Nevertheless, you may wish to install bat boxes and leave swallow nests undisturbed, since every little bit helps.

\section{Mosquito traps}

Mosquito traps attract mosquitoes with light, carbon dioxide $\left(\mathrm{CO}_{2}\right)$, and/or other substances like octenol. Carbon dioxide is a component of breath, which mosquitoes use to find humans and animals. Studies have shown that it is difficult to deplete mosquitoes in an area using traps. While traps remove some mosquitoes from the air, they also attract biting mosquitoes. Traps should not be placed close to human or animal habitation, and they should not be relied upon exclusively for control.

\section{Broad-spectrum insecticides: Organophosphates, pyrethroids and others}

A number of broad-spectrum insecticides are approved by the federal and state governments for use in mosquito control. In California, only specially licensed public health personnel and commercial applicators may apply these pesticides for mosquito control. Broad-spectrum insecticides are toxic at some level to most insects and some other forms of life, as well as to mosquitoes. You can buy some of the same pesticides over the counter for use on your property, but you are bound by law to use these products only as directed. Uses not allowed by the pesticide label are illegal and may be dangerous to humans, animals, and the environment. Because of the restrictions on pesticide use for mosquito control, the following information on chemicals used against adult mosquitoes is provided only to give you a greater understanding of methods used by MVCDs.

Chemicals in use for adult mosquito control are not thought to persist for more than several weeks in the environment, although this can vary according to local con- 
ditions. Two of the most common families of chemicals are organophosphates (such as malathion and naled) and pyrethroids (such as permethrin, pyrethrin, and resmethrin). These neurotoxins interfere with nerve cell operation. The concentrates must be handled with care because they are toxic to humans and other higher animals, as well as to insects. However, they are considered safe for vertebrate animals at levels used in mosquito control. Broad-spectrum insecticides are usually less expensive than the biological controls described above.

Pesticides can be used against adults by fogging them over the landscape at dusk or dawn to kill flying mosquitoes when they are most active. Trained personnel employ this method to control outbreaks of adult mosquitoes. However, fogging requires atmospheric conditions with a minimum of wind, usually less than 10 miles per hour $(16 \mathrm{~km} / \mathrm{h})$, and fogs are not very effective at penetrating dense vegetation. Also, the results of fogging are temporary: mosquitoes may fly back into an area soon after fogging. Even under the best conditions, some mosquitoes in secluded places will escape, and a total elimination of mosquitoes cannot be expected. Fogging also kills nontarget flying insects, including mosquito predators.

\section{Mosquito Abatement and Vector Control Districts}

Publicly supported mosquito abatement districts and mosquito vector control districts have been formed in many areas to carry out local mosquito control. The area may be a county or other political subdivision. California residents can find out whether they live within a mosquito abatement district by referring to the Mosquito and Vector Control Association of California Web site, http://mvcac.org, or by consulting the

"Government" pages in a telephone book. Advice and some services are free but others may incur fees.

Mosquito abatement districts target most of their services toward mosquito control and public education about mosquito problems and prevention. Mosquito and vector control districts also offer these services, but additionally address problems created by a wider variety of arthropods and sometimes other kinds of animals (e.g. ticks, wasps, rats, etc.). The distinction between the two types of district is, however, in practice, informal.

If you and your neighbors are interested in forming a district, or are interested in the organization, duties, and financing of a district, consult the Vector Borne Diseases Section of the State Department of Public Health in Sacramento. Laws and regulations applying to MVCDs are contained in the California Health and Safety Code $\S \S 2000-2093$.

MVCDs serve the public and are more than happy to work with landowners to help them solve particular problems. Because mosquitoes can pose a public health problem for entire communities, MVCDs have the legal right to access private property for the purposes of mosquito abatement under California Health and Safety Code $\S \S 2040-2055$.

\section{Community Cooperation}

As you may have guessed by the impressive list of mosquito habitats in this publication, public agencies can never control all the mosquitoes on every property. Community cooperation is essential.

One of the most important steps in cooperative mosquito control work is to establish a master drainage plan for the area. All new construction such as land leveling, roads, canals, housing projects, and industrial developments that use water or produce wastewater should be tied into the master plan. Although this may appear difficult in rapidly growing communities, a little coordination and planning at the beginning of projects can avoid major headaches later. If you become aware of a new project 


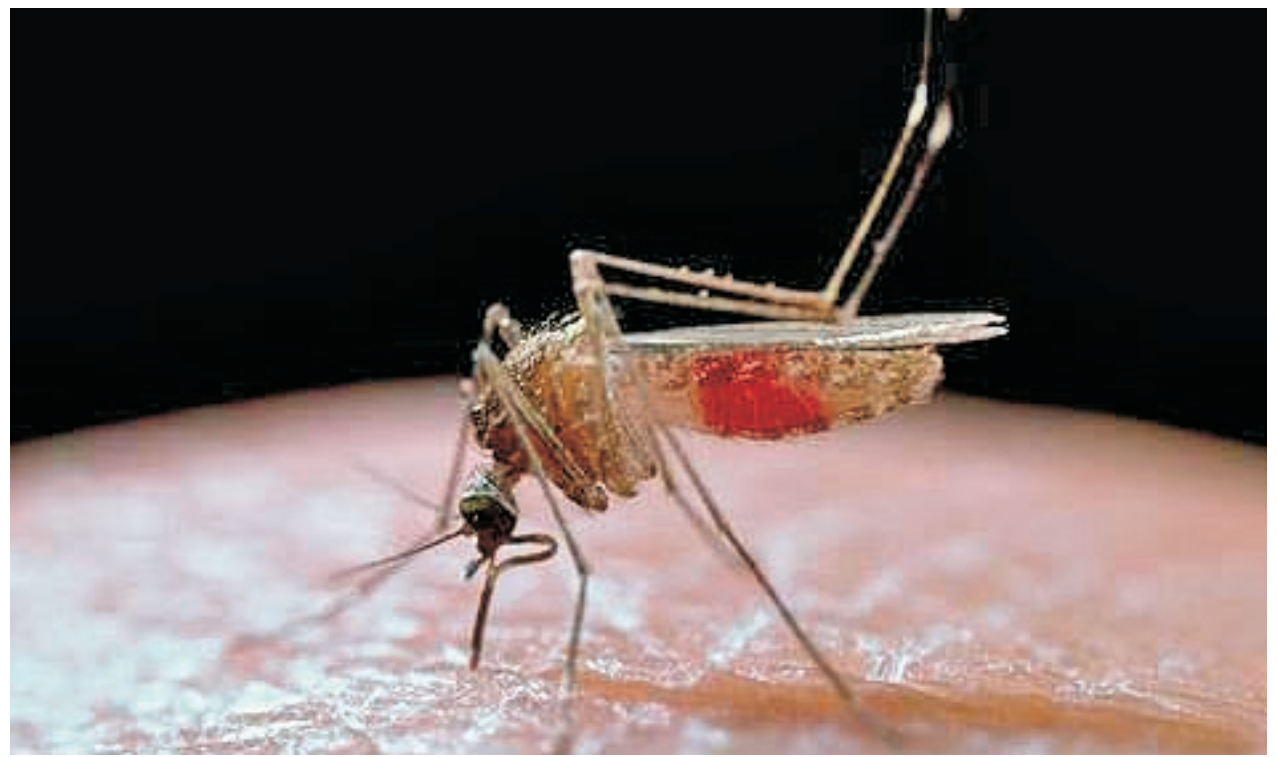

Figure 8. Culex tarsalis. Photo by Jack Kelly Clark. in your area, it is helpful to make sure that mosquito control and drainage have been considered and that the local MVCD is aware of the project.

\section{COMMON MOSQUITOES AND THEIR LIFE CYCLES}

You must understand the life cycle of mosquitoes to control them. The life cycle of all mosquito species consists of four parts: egg, larva, pupa, and adult. Nearly all species have adult females that bite animals to supply nutrients for one or more batches of eggs.

However, each species has its own peculiarities as to where eggs are laid, how long it takes for larvae to develop, and what happens to adults in winter.

This sections provides brief descriptions of some major mosquitoes that occur in California. Because 53 species of mosquitoes are found in California, this section includes only some of the major disease carriers and pest species that are particularly abundant in agricultural areas. Local MVCDs can provide more detailed information about species in your area. Note that common names are sometimes different from place to place. The Latin name in italics is the official scientific name.

\section{Culex spp. Mosquitoes}

Several Culex spp. mosquitoes can carry viruses that cause encephalitis, a dangerous brain disease. Mosquitoes in this group lay eggs on top of the water, in floating rafts. Females can lay up to 300 eggs at a time, sometimes as many as 7 batches over a 2month period, although most adult females do not survive this long. Adults have blunt abdomens and short palps, feelers that lie next to the long proboscis with which the female mosquito bites.

\section{Western encephalitis mosquito (Culex tarsalis)}

The western encephalitis mosquito (fig. 8) is probably California's most important species from the perspective of disease and mosquito control. It can carry viruses that cause encephalitis (sleeping sickness), which can be transmitted to humans and horses. It is very effective in transmitting West Nile virus, St. Louis encephalitis virus, and western equine encephalitis virus. This species is widespread, occurring in every county in California.

Larvae take from 8 days to several weeks to reach the adult stage, with faster development in warmer waters. However, they do not survive well below $70^{\circ} \mathrm{F}\left(21^{\circ} \mathrm{C}\right)$ or above $95^{\circ} \mathrm{F}\left(35^{\circ} \mathrm{C}\right)$. In the Central Valley of California, populations peak in June or July, but larvae may be found into early winter. Great numbers of larvae are found in rice fields, ditches, and in practically any freshwater pool, especially around weedy edges. They tolerate salinity up to 1 percent and can inhabit lightly polluted waters, but not very polluted waters. In some areas, $C$. tarsalis populations have become resistant to certain pesticides.

The adult encephalitis mosquito can fly for up to 10 to 15 miles (16 to $24 \mathrm{~km}$ ), but most stay close to the area in which they were bred. They prefer feeding at dusk and night, 


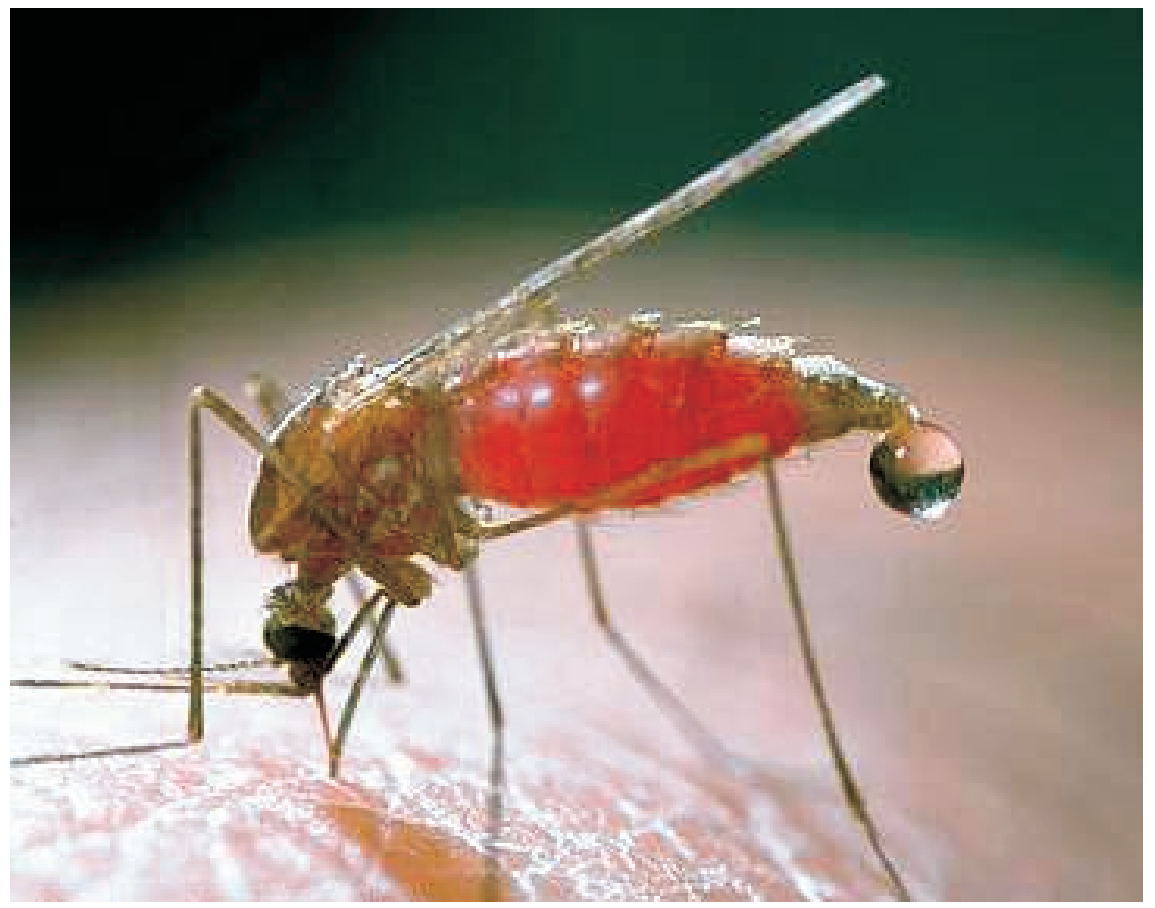

Figure 9. Anopheles freeborni. Photo by Jack Kelly Clark. but may bite during the day in deep shade. Females obtain blood meals from birds or mammals and can transmit diseases between these groups. They are active in spring through fall. They survive through the winter as adults in barns, culverts, caves, and similar dark, protected places.

\section{Northern house mosquito (Culex pipiens) and Southern house mosquito (Culex quinquefasciatus)}

These two closely related mosquitoes have a life cycle and biting habits similar to C. tarsalis but they favor water with organic pollution. Thus they are common in areas subject to manure and dairy runoff, fertilized areas, dirty bird baths, and improperly constructed septic equipment. They are very similar in appearance. C. pipiens is more common in the north and cooler coastal regions of California, while C. quinquefasciatus (sometimes called "quinqs") are more common in the south. Both species are capable of transmitting encephalitis viruses. These mosquitoes are particularly good at getting into houses.

\section{Anopheles spp. Mosquitoes}

Anopheles spp. mosquitoes are capable of carrying malaria. Mosquito control and medicine have eliminated sources of malaria in the United States, but these mosquitoes can transmit malaria from persons that have been infected abroad. These mosquitoes lay hundreds of separate eggs on standing water. Unlike most other mosquito larvae, Anopheles spp. larvae lie parallel against the water's surface, instead of hanging down vertically. They have a small breathing valve at the end of the abdomen, rather than a dark shiny tube, or siphon, like most other species. Adult females have palps that are as long as the proboscis. Females also "stand on their heads" when feeding.

\section{Western malaria mosquito (Anopheles freeborni)}

The western malaria mosquito (fig. 9) was once feared as a carrier of malaria; now it is mostly feared for its numbers and appetite. It is widespread and can occur in practically any standing fresh water. It becomes abundant in rice fields or other wetlands in late summer, or earlier in cooler areas.

A female can lay successive batches of up to 300 eggs during the breeding season. Larval periods range from 12 to 20 days (longer in cooler weather). Adult females bite at dusk and dawn and prefer to feed on mammals. Most adults stay within a few miles of their source, but they may migrate further when seeking hibernation sites in fall. Early broods are found in pools, ditches, and wetlands. Later they move into the rice fields if these are available. By September, if no control efforts have been made, people and livestock for miles around can be assailed by swarms of these mosquitoes.

Adults hibernate in protected areas in winter. Many adults survive hibernation and some come out during warm periods in the winter. The number coming out of hibernation on the first warm days of early spring is frequently so great that people mistakenly think that a new batch has hatched from the fields. 


\section{Ochlerotatus (Aedes) spp. Mosquitoes}

These mosquitoes, known as floodwater mosquitoes, lay eggs on damp soils or in dry treeholes and containers rather than on standing water. The larvae and adults are similar to Culex spp. in overall appearance, but the adults have pointed abdomens. Summer-breeding species often develop very rapidly; these species are the main reason for the rule that no wastewater should be allowed to stand for more than 4 days in warm weather. The eggs of these mosquitoes develop on dry land but do not hatch until the area is flooded. By virtue of their rapid larval development, they are sometimes out of the water before most predators have even had a chance to colonize, so natural biological control gets little chance to work. Eggs can build up in the soil because females lay successive batches of eggs, so great numbers can hatch after flooding. Worse yet, these mosquitoes bite during the day as well as at dusk and prefer to feed on mammals. Many Ochlerotatus spp. were formerly placed in the genus Aedes; older publications use Aedes, followed by the same species names given below.

\section{Irrigated-pasture mosquito (Ochlerotatus nigromaculis)}

The irrigated-pasture mosquito swarms in hordes to attack livestock and ranchers. The eggs are laid on damp soil, and a new brood hatches with each irrigation. In hot weather, adults can emerge within 4 days after the eggs are wetted. This species is widely distributed in California but is predominant in the San Joaquin Valley. With such a short life cycle and a brood emergence with each irrigation, there may be 10 or more broods during the summer. It develops slowly in the spring, faster in summer, and tapers off in the fall, and it passes the winter in the egg stage in the soil of pastures. The irrigatedpasture mosquito is a vicious day-biter and in general does not migrate far. It is not considered to be an important carrier of disease.

\section{Wetlands mosquito (Ochlerotatus melanimon)}

The wetlands mosquito has a similar life cycle and habitat to O. nigromaculis, but in addition to irrigated fields it breeds in deeper waters such as seasonal wetlands and rice fields and is more cold tolerant. Laboratory tests show that it can carry West Nile virus.

\section{Field mosquito, or pale marsh mosquito (Ochlerotatus dorsalis)}

The field mosquito is a big problem for growers and communities near coastal marshes. Emerging adults often fly 10 miles $(16 \mathrm{~km})$ or more inland to feed. It can become quite abundant in brackish areas and salt marshes, including those in eastern parts of the state. Its habits and life cycle are similar to those of the irrigated-pasture mosquito, but it develops somewhat more slowly, taking over 1 week to grow from egg to adult even in warm weather. Larvae can be found from January through October. Eggs do not develop in cold weather. The eggs are the overwintering stage; adults die off in early winter.

\section{California salt marsh mosquito (Ochlerotatus squaminger)}

This mosquito also breeds in farms with coastal marshes. It is a winter breeder, and larvae develop slowly in the cold water. It has only 1 generation per year. Biting females can appear in enormous numbers in springtime.

\section{Western treehole mosquito (Ochlerotatus sierrensis)}

The western treehole mosquito breeds in treeholes and other containers, especially in the foothills of the Coastal Range and Sierra Nevada. Females lay batches of 200 to 300 eggs. The eggs hatch when rain fills the containers with water. Development is slow and adults emerge between late February and June. Usually there is only 1 brood per year. This day-biting mosquito is annoying to humans but can be fatal to dogs because it carries dog heartworm. 


\section{ACKN OWLEDGMENTS}

Robert K Washino gave valuable help in updating the section on mosquito biology. Bruce Eldridge provided editorial assistance and valuable clarifications. Comments on various areas were provided by the North Salinas M.A.D., Jim Camy, Anton Cornel, Deborah Dritz, Mary Louise Flint, Mike Kimball, Deanne Meyer, Alec Gerry, Larry Schwankl, Richard Takahashi, and two anonymous reviewers. Larry Strand assisted with the photographs.

\section{FOR FURTHER INFORMATION}

Managing Mosquitoes in Stormwater Treatment Devices, ANR Publication 8125, 2004. http://anrcatalog.ucdavis.edu/pdf/8125.pdf.

Managing Mosquitoes in Surface-Flow Constructed Treatment Wetlands, ANR Publication 8117, 2003. http://anrcatalog.ucdavis.edu/pdf/8117.pdf.

Mosquito and Vector Control Association of California Web site, http://mvcac.org.

Mosquitoes: Pest Notes for Homes and Landscapes, ANR Publication 7451, 1998. http://www.ipm.ucdavis.edu/PDF/PESTNOTES/pnmosquitoes.pdf.

Mosquitoes of California, 3rd edition, ANR Publication 4084, 1978.

To order or obtain printed publications and other products, visit the ANR

Communication Services online catalog at http://anrcatalog.ucdavis.edu. You can also place orders by mail, phone, or FAX, or request a printed catalog of our products from:

University of California

Agriculture and Natural Resources

Communication Services

6701 San Pablo Avenue, 2nd Floor

Oakland, California 94608-1239

Telephone: (800) 994-8849 or (510) 642-2431, FAX: (510) 643-5470

E-mail inquiries: danrcs@ucdavis.edu

An electronic version of this publication is available on the ANR Communication Services Web site at http://anrcatalog.ucdavis.edu.

Publication 8158

(C) 2005 by the Regents of the University of California, Division of Agriculture and Natural Resources. All rights reserved.

The University of California prohibits discrimination or harassment of any person on the basis of race, color, national origin, religion, sex, gender identity, pregnancy (including childbirth, and medical conditions related to pregnancy or childbirth), physical or mental disability, medical condition (cancer-related or genetic characteristics), ancestry, marital status, age, sexual orientation, citizenship, or status as a covered veteran (covered veterans are special disabled veterans, recently separated veterans, Vietnam era veterans, or any other veterans who served on active duty during a war or in a campaign or expedition for which a campaign badge has been authorized) in any of its programs or activities. University policy is intended to be consistent with the provisions of applicable State and Federal laws.

Inquiries regarding the University's nondiscrimination policies may be directed to the Affirmative Action/Staff Personnel Services Director, University of California, Agriculture and Natural Resources, 300 Lakeside Drive, 6th Floor, Oakland, CA $94612-3550$ (510) 987-0096. For a free catalog of other publications, call (800) 994-8849. For help downloading this publication, call (530) 297-4445.

To simplify information, trade names of products have been used. No endorsement of named or illustrated products is intended, nor is criticism implied of similar products that are not mentioned or illustrated.

This publication has been anonymously peer reviewed for technical accuracy by University of California scientists and other qualified professionals. This review process was managed by the ANR Associate Editor for Pest Management.

pr-8/05-SB/CR

ISBN 978-1-60107-327-3 